\title{
The Effect of Silage Cutting Height on the Nutritive Value of a Normal Corn Silage Hybrid Compared with Brown Midrib Corn Silage Fed to Lactating Cows
}

\author{
L. Kung Jr., ${ }^{1}$ B. M. Moulder, C. M. Mulrooney, R. S. Teller, and R. J. Schmidt \\ Department of Animal and Food Sciences, University of Delaware, Newark 19716-2150
}

\begin{abstract}
A brown midrib (BMR) hybrid and a silage-specific non-BMR (7511FQ) hybrid were harvested at a normal cut height leaving 10 to $15 \mathrm{~cm}$ of stalk in the field. The non-BMR hybrid was also cut at a greater height leaving 45 to $50 \mathrm{~cm}$ of stalk. Cutting high increased the concentrations of dry matter $(+4 \%)$, crude protein $(+5 \%)$, net energy for lactation $(+3 \%)$, and starch $(+7 \%)$, but decreased the concentrations of acid detergent fiber $(-9 \%)$, neutral detergent fiber $(-8 \%)$, and acid detergent lignin $(-13 \%)$ for $7511 \mathrm{FQ}$. As expected, the BMR corn silage was $30 \%$ lower in lignin concentration than $7511 \mathrm{FQ}$. After $30 \mathrm{~h}$ of in vitro ruminal fermentation, the digestibility of neutral detergent fiber for normal cut $7511 \mathrm{FQ}$, the same hybrid cut high, and the normal cut BMR hybrid were 51.7, 51.4, and $63.5 \%$, respectively. Twenty-seven multiparous lactating cows were fed a total mixed ration composed of the respective silages (45\% of dry matter) with alfalfa haylage $(5 \%)$, alfalfa hay $(5 \%)$, and concentrate (45\%) (to make the TMR isocaloric and isonitrogenous) in a study with a $3 \times 3$ Latin square design with 21 -d periods. Milk production was greater for cows fed the BMR hybrid (48.8 $\mathrm{kg} / \mathrm{d}$ ) compared with those fed the normal cut $7511 \mathrm{FQ}$ $(46.8 \mathrm{~kg} / \mathrm{d})$ or cut high $(47.7 \mathrm{~kg} / \mathrm{d})$. Dry matter intake was not affected by treatment. Feed efficiency for cows fed the BMR silage (1.83) was greater than for those fed high-cut 7511FQ (1.75), but was not different from cows fed the normal cut $7511 \mathrm{FQ}$ (1.77). Cows fed the BMR silage had milk with greater concentrations of lactose but lower milk urea nitrogen than cows on other treatments. Harvesting a silage-specific, non-BMR corn hybrid at a high harvest height improved its nutritive content, but the improvement in feeding value was not equivalent to that found when cows were fed BMR corn silage.
\end{abstract}

Received March 27, 2007.

Accepted November 23, 3007.

${ }^{1}$ Corresponding author: lksilage@udel.edu
Key words: corn silage, digestibility, dairy cow, brown midrib corn

\section{INTRODUCTION}

Wu and Roth (2005) summarized the data from 11 studies in which corn silage was cut low or high. They reported that cutting high (leaving about $50 \mathrm{~cm}$ of stalk in the field) increased the concentrations of $\mathrm{CP}$ and $\mathrm{NE}_{\mathrm{L}}$, and increased NDF digestion and milk produced per ton of silage compared with cutting at a more normal height (about $17 \mathrm{~cm}$ ). However, cutting high resulted in a decrease in potential milk produced per acre. In lactation studies, Wu et al. (2001) and Neylon and Kung (2003) reported small increases in milk production when high-cut corn silage was fed, but milk fat percentage was decreased in both studies. Dominguez and Satter (2003) and Dominguez et al. (2002) reported no advantage to feeding high-cut corn silage to cows. Lewis et al. (2004) suggested that cutting corn silage high may be a good management practice for leafy silage hybrids but not for brown midrib (BMR) hybrids, because cutting high did little to improve the quality of the harvested BMR and decreased DM yields.

The superior feeding value of BMR corn silage has been documented in several studies (Oba and Allen, 1999; Ebling and Kung, 2004). The lower concentration of lignin in BMR corn silage is the primary factor responsible for improvements in fiber digestibility. In a previous study, Dominguez et al. (2002) reported that cows fed BMR corn silage cut at $23 \mathrm{~cm}$ tended to produce more milk $(1.1 \mathrm{~kg} / \mathrm{d}, P<0.09)$ than those fed a conventional corn silage hybrid cut at the same height. However, cows fed that BMR silage produced similar amounts of milk compared with cows fed the conventional corn silage hybrid harvested at a height of $71 \mathrm{~cm}$.

The objective of this study was to evaluate the yield and feeding value of a dual-purpose corn silage hybrid harvested at a normal and high cut with BMR corn silage harvested at a normal cut length when incorporated into TMR that were isocaloric and isonitrogenous. 


\section{MATERIALS AND METHODS}

Mycogen (Dow AgroSciences LLC, Indianapolis, IN) varieties $7511 \mathrm{FQ}$ (a silage-specific, non-BMR hybrid) and F2F797 (a BMR hybrid) were planted in spring 2004 under dry land conditions in one field. Corn was planted at the University of Delaware Dairy in fields of silt loam soil at a theoretical planting density of 72,500 seeds/ha $(29,000$ seeds per acre) in $0.76-\mathrm{m}$ (30in.) rows. All other agronomic practices were similar. Corn was monitored for milk-line and whole-plant DM content after the early dent stage of maturity. Wholeplant corn was harvested with a New Holland FP230 (New Holland, PA) pull-type harvester at a theoretical chop length of $1.90 \mathrm{~cm}$ (3/4 in.) equipped with a mechanical processor when the DM content was approximately 33 to $35 \%$. Treatments were 1) $7511 \mathrm{FQ}$ cut to leave 10 to $15 \mathrm{~cm}$ (4 to $6 \mathrm{in}$.) of stalk, 2) $7511 \mathrm{FQ}$ cut to leave 46 to $51 \mathrm{~cm}$ (18 to $20 \mathrm{in}$.) of stalk, and 3) BMR cut to leave 10 to $15 \mathrm{~cm}$ (4 to 6 in.) of stalk. Because of threatening weather from a hurricane, the BMR hybrid was harvested slightly earlier than planned (about 30\% DM). On the same day of harvest, yield estimates were made from 5 random locations in the field for each of the 3 treatments after cutting. Forage from each treatment was ensiled in bag silos and allowed to ferment for 6 mo before feedout.

A lactation study was conducted from February to May 2005. Animal care and use was according to protocols approved by the University of Delaware, College of Agriculture and Natural Resources Animal Care and Use Committee. Twenty-seven multiparous Holstein cows (average $81 \pm 48 \mathrm{DIM}$ and averaging about $45 \mathrm{~kg}$ of milk/d at the start of the study) were housed in a sand-bedded, free-stall barn equipped with Calan gates (American Calan, Northwood, NH) for the measurement of individual feed intake. Cows were allowed to adjust to the gates for a 2 -wk period. Cows were then blocked by milk production, DIM, and lactation number and randomly assigned to 1 of the 3 treatments in 9 simultaneously replicated $3 \times 3$ Latin squares. Each of the 3 periods consisted of $21 \mathrm{~d}$, with data from the final $10 \mathrm{~d}$ of each period used for analyses. The treatments consisted of 3 TMR that contained $45 \%$ (DM basis) of one of the harvested corn silages, $45 \%$ concentrate, $5 \%$ alfalfa hay, and $5 \%$ alfalfa haylage. The concentrates (Table 1) were formulated to make the TMR isonitrogenous and isocaloric such that the projected TMR would meet requirements for cows averaging $615 \mathrm{~kg}$ of BW consuming $25.8 \mathrm{~kg}$ of DM and producing $45.4 \mathrm{~kg}$ of milk/d with a $3.7 \%$ fat test (NRC, 2001). Cows were offered their TMR once daily at $105 \%$ of their expected intake to ensure ad libitum consumption and had access to fresh water at all times. Daily milk production was
Table 1. Ingredient concentrations (DM basis) of the concentrates used in the TMR fed to lactating cows ${ }^{1}$

\begin{tabular}{|c|c|c|c|}
\hline Item & $\begin{array}{c}\text { Normal-cut } \\
7511 \mathrm{FQ}\end{array}$ & $\begin{array}{c}\text { High-cut } \\
7511 \mathrm{FQ}\end{array}$ & $\begin{array}{c}\text { BMR } \\
\text { F2F797 }\end{array}$ \\
\hline Soybean meal & 20.93 & 20.84 & 21.04 \\
\hline Wheat middlings & 15.95 & 18.87 & 11.65 \\
\hline Easi-flo cottonseed & 10.32 & 10.28 & 10.38 \\
\hline Soyhulls & 6.36 & 8.19 & 3.64 \\
\hline Superflake corn & 10.72 & 6.63 & 16.75 \\
\hline Amino plus ${ }^{2}$ & 5.77 & 6.37 & 4.90 \\
\hline Soybeans, flaked & 7.32 & 5.47 & 10.05 \\
\hline Cottonseed meal & 4.69 & 4.94 & 4.33 \\
\hline Limestone, fine & 2.67 & 2.71 & 2.63 \\
\hline Distillers grains, reground & 2.17 & 2.30 & 1.97 \\
\hline Impact 74 protein blend ${ }^{3}$ & 2.01 & 2.15 & 1.82 \\
\hline Molasses-wet/mold inhibitor & 1.59 & 1.59 & 1.60 \\
\hline Salt-fine solar/mixing & 1.54 & 1.59 & 1.47 \\
\hline Megalac $^{4}$ & 1.29 & 1.30 & 1.27 \\
\hline Stabilized fat & 1.08 & 1.13 & 1.01 \\
\hline Sodium bicarbonate-SQ 810 & 0.91 & 0.92 & 0.90 \\
\hline Ground corn & 0.46 & 0.59 & 0.27 \\
\hline Dicalcium phosphate, $21 \% \mathrm{P}$ & 0.55 & 0.57 & 0.52 \\
\hline Magnesium oxide mix & 0.49 & 0.51 & 0.46 \\
\hline Condition aid & 0.35 & 0.37 & 0.32 \\
\hline Whey, edible dry & 0.32 & 0.32 & 0.31 \\
\hline Soybean oil & 0.34 & 0.34 & 0.34 \\
\hline Yeast culture $^{5}$ & 0.27 & 0.27 & 0.27 \\
\hline Corn gluten meal & 0.52 & 0.27 & 0.90 \\
\hline Urea & 0.23 & 0.28 & 0.15 \\
\hline Superbind & 0.19 & 0.21 & 0.17 \\
\hline Dynamate $^{6}$ & 0.19 & 0.18 & 0.19 \\
\hline Pennfield-quadra ${ }^{7}$ & 0.15 & 0.15 & 0.15 \\
\hline Alfalfa meal $17 \%$ & 0.12 & 0.12 & 0.12 \\
\hline Ruminant trace minerals ${ }^{8}$ & 0.12 & 0.12 & 0.11 \\
\hline Selenium, $0.06 \% \mathrm{Se}$ & 0.11 & 0.12 & 0.10 \\
\hline Calcium sulfate & 0.09 & 0.11 & 0.06 \\
\hline $\mathrm{A}, \mathrm{D}$, and $\mathrm{E}$ vitamin premix ${ }^{9}$ & 0.07 & 0.08 & 0.06 \\
\hline Organic selenium premix, $120 \mathrm{ppm}$ & 0.06 & 0.07 & 0.05 \\
\hline Niacin, $99 \%$ & 0.04 & 0.04 & 0.04 \\
\hline
\end{tabular}

${ }^{1}$ Diets included a normal corn silage hybrid (Mycogen $7511 \mathrm{FQ}$ ) harvested to leave 10 to $15 \mathrm{~cm}$ of stalk (normal cut) or 46 to $51 \mathrm{~cm}$ of stalk (high cut) or a BMR hybrid (Mycogen F2F797) harvested to leave 10 to $15 \mathrm{~cm}$ of stalk.

${ }^{2} \mathrm{~A}$ source of rumen bypass lysine and methionine (Ag Processing Inc., Omaha, NE).

${ }^{3}$ Contained blood meal, fish meal, gluten meal, and feather meal. Guaranteed analysis of 74\% CP and 2.5\% fat (Venture Milling Ltd., Seaford, DE).

${ }^{4}$ Calcium salts of long-chain fatty acids; minimum fat of $82.5 \%$ (Church and Dwight Co., Inc. Princeton, NJ).

${ }^{5} \mathrm{XP}$ yeast (Diamond V Mills, Cedar Rapids, IA).

${ }^{6}$ Minimum of $22 \% \mathrm{~S}, 18 \% \mathrm{~K}, 11 \% \mathrm{Mg}$ (Mar-Gro, Lancaster, PA).

${ }^{7}$ Minimum of $2 \% \mathrm{Zn}, 3.75 \% \mathrm{Mn}$, and $6.75 \% \mathrm{Zn}$ as metal proteinates (Pennfield Corp., Lancaster, PA).

${ }^{8}$ Minimum $8.6 \% \mathrm{Ca}, 1,35 \% \mathrm{Cu}, 4 \% \mathrm{Fe}, 7.5 \% \mathrm{Mn}, 12 \% \mathrm{Zn}, 1,000$ ppm Co, and 2,500 ppm I (Eastern Minerals Inc., Bainbridge, GA).

${ }^{9}$ Minimum of 22,000,000 IU/kg, 5,500,000 IU/kg and 110,000 IU/ $\mathrm{kg}$, respectively (Pennfield Corp.).

recorded twice daily. Milk was sampled from 2 consecutive milkings during each week during of the study. Milk was analyzed for protein, fat, MUN, SCC, and lactose by infrared analyses (Dairy One Laboratories, University Park, PA). Body weights were recorded on 
Table 2. Plant height, numbers of plants, and DM yield from corn silages ${ }^{1}$

\begin{tabular}{|c|c|c|c|c|}
\hline Item $^{2}$ & $\begin{array}{c}\text { Normal-cut } \\
7511 \mathrm{FQ}\end{array}$ & $\begin{array}{c}\text { High-cut } \\
7511 \mathrm{FQ}\end{array}$ & $\begin{array}{c}\text { BMR } \\
\text { F2F797 }\end{array}$ & SEM \\
\hline Plant height, $\mathrm{m}$ & $3.04^{\mathrm{ab}}$ & $3.09^{\mathrm{a}}$ & $2.92^{\mathrm{b}}$ & 0.03 \\
\hline Number of plants/5.33-m row & 29.4 & 29.6 & 28.8 & 1.40 \\
\hline $\mathrm{DM}$ yield, t/ha & $25.1^{\mathrm{a}}$ & $20.9^{\mathrm{b}}$ & $22.8^{\mathrm{ab}}$ & 0.81 \\
\hline
\end{tabular}

${ }^{\mathrm{a}, \mathrm{b}}$ Means in rows with unlike superscripts differ $(P<0.05)$.

${ }^{1}$ Diets included a normal corn silage hybrid (Mycogen 7511FQ) harvested to leave 10 to $15 \mathrm{~cm}$ of stalk (normal cut) or 46 to $51 \mathrm{~cm}$ of stalk (high cut) or a BMR hybrid (Mycogen F2F797) harvested to leave 10 to $15 \mathrm{~cm}$ of stalk.

${ }^{2}$ Values represent the average height of plants, number of plants, and DM yield from five 5.33-m rows. Dry matter yield was adjusted to a hectare basis.

2 consecutive days at the start and end of the treatment period and then weekly during the treatment period.

Samples of alfalfa hay, alfalfa haylage, corn silages, and the treatment TMR were collected 3 times weekly and pooled each week for chemical analyses. A sample of the concentrate was collected once weekly. Dry matter of the forages was determined in a forced-draft oven set at $60^{\circ} \mathrm{C}$ for $48 \mathrm{~h}$. Dry matter of the hay and concentrates was determined in a forced-draft oven set at $100^{\circ} \mathrm{C}$ for $24 \mathrm{~h}$. The DM content of feeds was used for weekly adjustment of the TMR. Feed samples were sent weekly to Cumberland Valley Analytical Laboratories (Maugansville, MD) for nutrient analysis via wet chemistry methods. Ash content was determined according to AOAC (2000) methods with the modification of using 0.5 -g sample weights and the furnace temperature at $535^{\circ} \mathrm{C}$. Crude protein was calculated as $\mathrm{N} \times 6.25$ after analyses of N (AOAC, 2000) using a Leco FP-528 Nitrogen Combustion Analyzer (Leco, St. Joseph, MI). Soluble protein was determined as described by Krishnamoorthy et al. (1982). Starch was determined as described by Holm et al. (1986). For corn silages, ADF and NDF were determined in our laboratory (Goering and Van Soest, 1970) using an Ankom Fiber Analyzer and acid detergent lignin (ADL; Goering and Van Soest, 1970) was determined using the Ankom Daisy incubation system (Ankom Inc., Macedon, NY). The digestibility of NDF (NDF-D) was determined on corn silage samples using the in vitro procedure described by Goering and Van Soest (1970) with some modifications. Those modifications included a) incubation of samples in $100-\mathrm{mL}$ polycarbonate tubes each sealed with a rubber stopper fitted with a glass tube with a rubber policeman (14-105A, Fisher Scientific, Pittsburgh, PA) with

Table 3. Composition (DM basis) of alfalfa hay, alfalfa haylage, and the concentrates fed throughout the study ${ }^{1,2}$

\begin{tabular}{|c|c|c|c|c|c|c|c|c|c|c|}
\hline \multirow[b]{2}{*}{ Item } & \multicolumn{2}{|c|}{$\begin{array}{l}\text { Alfalfa } \\
\text { hay }\end{array}$} & \multicolumn{2}{|c|}{$\begin{array}{c}\text { Alfalfa } \\
\text { haylage }\end{array}$} & \multicolumn{2}{|c|}{$\begin{array}{c}\text { Concentrate, } \\
\text { normal-cut } 7511 \mathrm{FQ}\end{array}$} & \multicolumn{2}{|c|}{$\begin{array}{c}\text { Concentrate, } \\
\text { high-cut } 7511 \mathrm{FQ}\end{array}$} & \multicolumn{2}{|c|}{$\begin{array}{c}\text { Concentrate, } \\
\text { normal-cut F2F797 }\end{array}$} \\
\hline & Mean & SD & Mean & $\mathrm{SD}$ & Mean & $\mathrm{SD}$ & Mean & SD & Mean & SD \\
\hline $\mathrm{DM}, \%$ & 87.73 & 0.78 & 42.26 & 6.38 & 86.94 & 0.55 & 87.03 & 0.54 & 86.89 & 0.61 \\
\hline $\mathrm{CP}, \%$ & 16.82 & 2.10 & 16.62 & 1.06 & 31.79 & 1.64 & 31.70 & 1.21 & 31.85 & 2.29 \\
\hline $\mathrm{SP}^{3}$ as $\% \mathrm{CP}$ & 47.88 & 2.85 & 62.11 & 6.06 & 20.95 & 4.30 & 23.05 & 3.82 & 19.53 & 5.61 \\
\hline $\mathrm{NE}_{\mathrm{L}}, \mathrm{Mcal} / \mathrm{kg}$ & 1.30 & 0.09 & 1.34 & 0.09 & 1.67 & 0.00 & 1.67 & 0.01 & 1.69 & 0.01 \\
\hline $\mathrm{ADF}, \%$ & 36.79 & 4.11 & 34.09 & 2.84 & 16.17 & 0.86 & 17.54 & 0.94 & 15.25 & 1.32 \\
\hline $\mathrm{ADL}^{4} \%$ & 7.43 & 0.75 & 7.24 & 1.03 & - & & - & & - & \\
\hline $\mathrm{NDF}, \%$ & 43.90 & 5.60 & 39.27 & 3.10 & 24.14 & 1.12 & 26.93 & 1.99 & 22.25 & 1.36 \\
\hline Ash, \% & 9.69 & 1.03 & 12.01 & 1.48 & 11.40 & 1.05 & 12.20 & 0.84 & 10.86 & 1.46 \\
\hline Starch, \% & 1.83 & 0.37 & 6.47 & 2.17 & 10.49 & 4.63 & 9.47 & 1.46 & 13.69 & 2.98 \\
\hline $\mathrm{Ca}, \%$ & 1.38 & 0.17 & 0.95 & 0.10 & 1.60 & 0.21 & 1.71 & 0.26 & 1.53 & 0.23 \\
\hline $\mathrm{P}, \%$ & 0.26 & 0.04 & 0.31 & 0.04 & 0.76 & 0.04 & 0.81 & 0.05 & 0.73 & 0.05 \\
\hline $\mathrm{Mg}, \%$ & 0.32 & 0.05 & 0.23 & 0.04 & 0.64 & 0.09 & 0.70 & 0.17 & 0.59 & 0.08 \\
\hline $\mathrm{K}, \%$ & 1.87 & 0.25 & 2.71 & 0.13 & 1.55 & 0.15 & 1.56 & 0.12 & 1.55 & 0.19 \\
\hline
\end{tabular}

${ }^{1}$ Diets included a normal corn silage hybrid (Mycogen 7511FQ) harvested to leave 10 to $15 \mathrm{~cm}$ of stalk (normal cut) or 46 to $51 \mathrm{~cm}$ of stalk (high cut) or a BMR hybrid (Mycogen F2F797) harvested to leave 10 to $15 \mathrm{~cm}$ of stalk.

${ }^{2}$ Each nutrient mean is the average from 9 weekly samples $( \pm \mathrm{SD})$.

${ }^{3}$ Soluble protein.

${ }^{4}$ Acid detergent lignin. 
a 5-mm slit to allow for venting of gas pressure; b) gentle manual swirling of the tubes at $3,6,9,20$, and $26 \mathrm{~h}$; and c) incubation for $30 \mathrm{~h}$. Ruminal fluid was obtained from a fistulated steer fed the TMR with normal-cut $7511 \mathrm{FQ}$.

Yield and nutrient analysis data for the corn silages were run through Milk2006 (Shaver and Lauer, 2006) to estimate milk/ton and milk/acre and were converted to the metric system for presentation. The data were analyzed as simultaneous $3 \times 3$ Latin squares as described by Morris (1999) by the GLM procedure of SAS (SAS Institute, 1999). Protected least significant difference was used to compare least squares means $(P<$ 0.05). Trends were noted when $P<0.12$.

\section{RESULTS AND DISCUSSION}

The fresh yield from harvested corn plants is shown in Table 2. The height of standing plants from $7511 \mathrm{FQ}$ was slightly greater than those of BMR F2F797. The number of harvested plants per 0.53-m row was similar between treatments. Dry matter yield was numerically lower $(-9.2 \%)$ for BMR compared with normal-cut $7511 \mathrm{FQ}$ but similar to the yield of high-cut $7511 \mathrm{FQ}$. The DM yield of high-cut $7511 \mathrm{FQ}$ was lower than that of normal-cut $7511 \mathrm{FQ}(-16.7 \%)$. This difference is greater than that reported from the average of 11 studies $(-7.4 \%)$ with high-cut corn silage summarized by $\mathrm{Wu}$ and Roth (2005).

The nutrient compositions of the alfalfa hay and haylage are shown in Table 3 and the nutrient compositions of the corn silages are shown in Table 4. High cutting of the corn hybrid $7511 \mathrm{FQ}$ increased the concentrations of $\mathrm{DM}(+4 \%), \mathrm{CP}(+5 \%), \mathrm{NE}_{\mathrm{L}}(+3 \%)$, and starch $(+7 \%)$, but decreased the concentrations of $\operatorname{ADF}(-9 \%)$, NDF (-8\%), and ADL (-13\%). Similar changes due to high cutting have been reported by us in a previous study (Neylon and Kung, 2003). The normal-cut BMR corn silage was harvested at $30.3 \% \mathrm{DM}$, which was slightly wetter than originally designed because of threatening weather (a hurricane in fall 2004). Although it was wetter than the harvested $7511 \mathrm{FQ}$ treatments, the BMR corn silage had greater concentrations of $\mathrm{ADF}$ and NDF, but a lower starch concentration than $7511 \mathrm{FQ}$. As expected, the normal-cut BMR had about $31 \%$ less ADL (2.20\%) than normal-cut $7511 \mathrm{FQ}(3.17 \%)$ and $20 \%$ less ADL than high-cut 7511FQ. The 30-h NDF-D of normal- and high-cut $7511 \mathrm{FQ}$ did not differ between treatments (51.7 vs. $51.4 \%$ ). Lack of a substantial effect on NDF-D due to high cutting is similar to that reported by Neylon and Kung (2003). In the summary of 11 studies by Wu and Roth (2005), high cutting increased NDF-D by an average of only about $5 \%$. In the current study, BMR corn silage had an in vitro
NDF-D (63.5\%) substantially greater than the $7511 \mathrm{FQ}$ corn silages. This $23 \%$ greater NDF-D is similar to the overall increase of $18.7 \%$ reported in a summary of BMR studies reported by Eastridge (1999). We hypothesize that the reason for small to no responses in NDF$\mathrm{D}$ from cutting high may be because the relationship between fiber and lignin is not different throughout the plant, although there is an apparent decrease in lignin content in high-cut silage. In contrast, changes in lignin concentration in BMR corn silage are probably more widespread and thus lead to an overall improvement in digestibility. Potential yield of milk per metric tonne of forage was greatest for BMR (1,595 kg/t), lowest for normal-cut $7511 \mathrm{FQ}(1,552 \mathrm{~kg} / \mathrm{t})$, and intermediate for high-cut $7511 \mathrm{FQ}(1,566 \mathrm{~kg} / \mathrm{t})$. Potential yield of milk produced per hectare was $25,010 \mathrm{~kg} /$ ha for normal-cut $7511 \mathrm{FQ}, 22,374 \mathrm{~kg} / \mathrm{ha}$ for BMR, and $20,898 \mathrm{~kg} / \mathrm{ha}$ for high-cut $7511 \mathrm{FQ}$.

The compositions of the TMR fed to lactating cows through the study are shown in Table 5. Analysis from collected samples showed that the TMR were similar for all treatments and averaged $17.5 \% \mathrm{CP}, 1.56 \mathrm{Mcal} /$ $\mathrm{kg}$ of $\mathrm{NE}_{\mathrm{L}}, 21.9 \% \mathrm{ADF}$, and $21.3 \%$ starch and the diets were slightly lower in energy than planned. We chose to make the TMR isonitrogenous and isocaloric because a case could be made that a producer would rebalance a TMR to meet specific requirements if the nutritive values of corn silage hybrids being fed were different. Differences in the ingredients used in the concentrates to make the diets isocaloric and isonitrogenous were kept to a minimum.

Dry matter intake, milk production and composition, and BW of cows are shown in Table 6. Dry matter intake (expressed as $\mathrm{kg} / \mathrm{d}$ or as a percentage of BW) was not different among treatments and averaged about $27 \mathrm{~kg} /$ d. In 2 previous lactation studies with high-cut corn silage, DMI was not affected by high cutting (Wu et al., 2001; Neylon and Kung, 2003). Cows fed BMR corn silage have had greater intakes in some (Oba and Allen, 1999; Tine et al., 2001) but not all studies (Dominguez et al., 2002; Dominguez and Satter, 2003). Weiss and Wyatt (2006) did not observe an improvement in DMI when cows were fed BMR silage and they suggested that one reason for their finding may have been that the BMR silage was compared with a silage hybrid with similar nutritive value (not the isogenic line) in their study. In addition, they suggested that levels of RDP may have been limiting in their diets. We propose that the lack of an intake effect from BMR silage in the current study and that of Weiss and Wyatt (2006) may be because both these studies had relatively short experimental periods ( $3 \mathrm{wk}$ ), which may not have been sufficient time for differences in intake to be expressed. In an earlier study from our group (Ebling and Kung, 
Table 4. The average composition (DM basis) and projected milk production (using MILK2006) of the corn silages fed during the lactation trial ${ }^{1,2}$

\begin{tabular}{|c|c|c|c|c|c|c|}
\hline \multirow[b]{2}{*}{ Item } & \multicolumn{2}{|c|}{$\begin{array}{l}\text { Normal-cut } \\
7511 \mathrm{FQ}\end{array}$} & \multicolumn{2}{|c|}{$\begin{array}{l}\text { High-cut } \\
7511 \mathrm{FQ}\end{array}$} & \multicolumn{2}{|c|}{$\begin{array}{l}\text { Normal-cut } \\
\text { F2F797 }\end{array}$} \\
\hline & Mean & $\mathrm{SD}$ & Mean & SD & Mean & SD \\
\hline $\mathrm{DM}, \%$ & 33.70 & 0.40 & 35.00 & 1.00 & 30.30 & 1.80 \\
\hline $\mathrm{CP}, \%$ & 7.10 & 0.23 & 7.43 & 0.37 & 7.46 & 0.39 \\
\hline $\mathrm{SP}^{3}$ as $\% \mathrm{CP}$ & 47.62 & 3.43 & 49.17 & 3.43 & 47.50 & 3.49 \\
\hline $\mathrm{NE}_{\mathrm{L}}, \mathrm{Mcal} / \mathrm{kg}$ & 1.61 & 0.02 & 1.65 & 0.02 & 1.58 & 0.02 \\
\hline $\mathrm{ADF}, \%$ & 25.84 & 1.18 & 23.59 & 1.09 & 27.01 & 1.21 \\
\hline $\mathrm{ADL}, 4 \%$ & 3.17 & 0.21 & 2.76 & 0.13 & 2.20 & 0.22 \\
\hline NDF, \% & 42.91 & 1.56 & 39.57 & 1.86 & 44.72 & 0.83 \\
\hline NDF-D, ${ }^{5} \%$ & 51.7 & 1.5 & 51.4 & 0.9 & 63.5 & 2.1 \\
\hline Ash, \% & 3.54 & 0.38 & 3.42 & 0.45 & 3.78 & 0.35 \\
\hline Starch, \% & 29.74 & 1.66 & 31.73 & 2.07 & 25.68 & 1.05 \\
\hline $\mathrm{Ca}, \%$ & 0.19 & 0.02 & 0.20 & 0.02 & 0.20 & 0.03 \\
\hline $\mathrm{P}, \%$ & 0.23 & 0.01 & 0.23 & 0.01 & 0.22 & 0.01 \\
\hline $\mathrm{Mg}, \%$ & 0.14 & 0.01 & 0.13 & 0.01 & 0.14 & 0.01 \\
\hline $\mathrm{K}, \%$ & 0.88 & 0.10 & 0.88 & 0.08 & 1.09 & 0.14 \\
\hline Milk, kg/t ${ }^{6}$ & 1,552 & & 1,566 & & 1,595 & \\
\hline Milk, kg/ha ${ }^{6}$ & 25,010 & & 20,898 & & 22,374 & \\
\hline
\end{tabular}

${ }^{1}$ Diets included a normal corn silage hybrid (Mycogen $7511 \mathrm{FQ}$ ) harvested to leave 10 to $15 \mathrm{~cm}$ of stalk (normal cut) or 46 to $51 \mathrm{~cm}$ of stalk (high cut) or a BMR hybrid (Mycogen F2F797) harvested to leave 10 to $15 \mathrm{~cm}$ of stalk.

${ }^{2}$ Each mean \pm SD is from 9 weekly composite samples.

${ }^{3}$ Soluble protein.

${ }^{4}$ Acid detergent lignin.

${ }^{5} \mathrm{NDF}$ digestion.

${ }^{6}$ Calculated using average values for MILK2006 and 30-h NDF-D of corn silages.

2004), cows fed BMR silage ate more DM than those fed a conventional hybrid, but the treatment period lasted $6 \mathrm{wk}$.

Milk production was greater for cows fed normal-cut BMR $(48.8 \mathrm{~kg} / \mathrm{d})$ than for those fed normal-cut $7511 \mathrm{FQ}$ $(46.8 \mathrm{~kg} / \mathrm{d})$ or high-cut $7511 \mathrm{FQ}(47.7 \mathrm{~kg} / \mathrm{d})$. Cows fed BMR silages have generally been more productive than those fed non-BMR hybrids in past studies when production was high (Oba and Allen, 1999; Ebling and Kung, 2004). However, in cows producing moderate amounts of milk ( $35 \mathrm{~kg} / \mathrm{d})$, Tine et al. (2001) did not observe a response in milk production when cows were fed BMR corn silage. Cows fed high-cut $7511 \mathrm{FQ}$ tended $(P<0.09)$ to produce more milk $(+0.9 \mathrm{~kg} / \mathrm{d})$ than those

Table 5. The average composition (DM basis) of the TMR fed during the lactation trial ${ }^{1,2}$

\begin{tabular}{|c|c|c|c|c|c|c|}
\hline \multirow[b]{2}{*}{ Item } & \multicolumn{2}{|c|}{$\begin{array}{c}\text { Normal-cut } \\
7511 \mathrm{FQ}\end{array}$} & \multicolumn{2}{|c|}{$\begin{array}{l}\text { High-cut } \\
7511 \mathrm{FQ}\end{array}$} & \multicolumn{2}{|c|}{$\begin{array}{c}\text { Normal-cut } \\
\text { F2F797 }\end{array}$} \\
\hline & Mean & $\mathrm{SD}$ & Mean & $\mathrm{SD}$ & Mean & $\mathrm{SD}$ \\
\hline DM, \% & 47.9 & 1.4 & 49.4 & 1.5 & 46.1 & 1.2 \\
\hline $\mathrm{CP}, \%$ & 17.5 & 0.88 & 17.5 & 1.67 & 17.5 & 1.07 \\
\hline $\mathrm{SP}^{3}$ as $\%$ of $\mathrm{CP}$ & 28.3 & 3.51 & 29.8 & 4.27 & 28.2 & 4.29 \\
\hline $\mathrm{NE}_{\mathrm{L}}, \mathrm{Mcal} / \mathrm{kg}$ & 1.56 & 0.02 & 1.56 & 0.02 & 1.56 & 0.02 \\
\hline $\mathrm{ADF}, \%$ & 22.2 & 1.02 & 21.9 & 1.65 & 21.7 & 1.42 \\
\hline NDF, $\%$ & 34.3 & 1.08 & 34.1 & 2.44 & 33.9 & 2.18 \\
\hline Ash, \% & 7.5 & 0.52 & 7.6 & 0.37 & 7.2 & 0.39 \\
\hline Starch, \% & 21.3 & 0.76 & 21.5 & 1.88 & 21.0 & 1.32 \\
\hline $\mathrm{Ca}, \%$ & 0.84 & 0.06 & 0.81 & 0.18 & 0.84 & 0.05 \\
\hline $\mathrm{P}, \%$ & 0.44 & 0.02 & 0.45 & 0.03 & 0.42 & 0.02 \\
\hline $\mathrm{Mg}, \%$ & 0.34 & 0.01 & 0.36 & 0.04 & 0.34 & 0.02 \\
\hline $\mathrm{K}, \%$ & 1.34 & 0.11 & 1.35 & 0.15 & 1.43 & 0.11 \\
\hline
\end{tabular}

${ }^{1}$ Diets included a normal corn silage hybrid (Mycogen 7511FQ) harvested to leave 10 to $15 \mathrm{~cm}$ of stalk (normal cut) or 46 to $51 \mathrm{~cm}$ of stalk (high cut) or a BMR hybrid (Mycogen F2F797) harvested to leave 10 to $15 \mathrm{~cm}$ of stalk.

${ }^{2}$ Each mean \pm SD is from 9 weekly composite samples.

${ }^{3}$ Soluble protein. 
Table 6. Effects of corn silage treatment on production measurements ${ }^{1}$

\begin{tabular}{|c|c|c|c|c|}
\hline Item & $\begin{array}{l}\text { Normal-cut } \\
7511 \mathrm{FQ}\end{array}$ & $\begin{array}{c}\text { High-cut } \\
7511 \mathrm{FQ}\end{array}$ & $\begin{array}{c}\text { Normal-cut } \\
\text { F2F797 }\end{array}$ & SEM \\
\hline DMI, kg/d & 26.9 & 27.3 & 26.8 & 0.3 \\
\hline DMI, $\%$ of BW & 3.63 & 3.70 & 3.61 & 0.04 \\
\hline Milk, $\mathrm{kg} / \mathrm{d}$ & $46.8^{\mathrm{b}}$ & $47.7^{\mathrm{b}}$ & $48.8^{\mathrm{a}}$ & 0.3 \\
\hline $3.5 \% \mathrm{FCM}, \mathrm{kg} / \mathrm{d}$ & $47.4^{\mathrm{c}}$ & $47.4^{\mathrm{c}}$ & $48.5^{\mathrm{d}}$ & 0.5 \\
\hline \multicolumn{5}{|l|}{ Milk components, $\%$} \\
\hline Fat, \% & $3.60^{\mathrm{a}}$ & $3.48^{\mathrm{b}}$ & $3.50^{\mathrm{ab}}$ & 0.04 \\
\hline Protein, \% & 2.88 & 2.87 & 2.87 & 0.01 \\
\hline Lactose, \% & $4.82^{\mathrm{b}}$ & $4.83^{\mathrm{b}}$ & $4.88^{\mathrm{a}}$ & 0.01 \\
\hline SCC $, \times 1,000$ & 217 & 321 & 261 & 54 \\
\hline MUN, mg/dL & $16.3^{\mathrm{a}}$ & $16.0^{\mathrm{a}}$ & $14.8^{\mathrm{b}}$ & 0.2 \\
\hline \multicolumn{5}{|l|}{ Milk component yield, $\mathrm{kg} / \mathrm{d}$} \\
\hline Fat & 1.67 & 1.65 & 1.69 & 0.02 \\
\hline Protein & $1.34^{\mathrm{b}}$ & $1.36^{\mathrm{b}}$ & $1.40^{\mathrm{a}}$ & 0.01 \\
\hline Feed efficiency (3.5\% FCM/DMI) & $1.77^{\mathrm{ab}}$ & $1.75^{\mathrm{b}}$ & $1.83^{\mathrm{a}}$ & 0.02 \\
\hline $\mathrm{BW}, \mathrm{kg}$ & 742 & 741 & 742 & 2 \\
\hline BW change, $\mathrm{kg} / \mathrm{d}$ & 0.45 & 0.55 & 0.70 & 0.17 \\
\hline
\end{tabular}

${ }^{\mathrm{a}, \mathrm{b}}$ Means in rows with unlike superscripts differ $(P<0.05)$.

${ }^{\mathrm{c}, \mathrm{d}}$ Means in rows with unlike superscripts differ $(P<0.12)$.

${ }^{1}$ Diets included a normal corn silage hybrid (Mycogen $7511 \mathrm{FQ}$ ) harvested to leave 10 to $15 \mathrm{~cm}$ of stalk (normal cut) or 46 to $51 \mathrm{~cm}$ of stalk (high cut) or a brown midrib hybrid (Mycogen F2F797) harvested to leave 10 to $15 \mathrm{~cm}$ of stalk.

fed normal-cut $7511 \mathrm{FQ}$ corn silage. Neylon and Kung (2003) reported that cows fed high-cut corn silage also tended to produce more milk $(+1.5 \mathrm{~kg} / \mathrm{d}, P<0.12)$ than those fed normal-cut corn silage. In contrast, Dominguez et al. (2002) and Dominguez and Satter (2003) did not observe any advantage in milk production when cows were fed high- vs. normal-cut corn silage. In the current study, increased cutting height decreased milk fat percentage for $7511 \mathrm{FQ}$ (3.60\% for normal cut vs. 3.48 for high cut) but did not affect daily yield of fat. Numerically lower percentages of milk fat have been reported in cows fed high-cut corn silage in past studies (Wu et al., 2001; Neylon and Kung, 2003). Protein percentages were similar among all treatments but cows fed normal-cut BMR produced more milk protein per day than did cows fed normal- and high-cut 7511FQ. Cows fed normal-cut BMR tended $(P<0.12)$ to produce more $3.5 \% \mathrm{FCM}$ than cows in other treatments. In a previous study, Dominguez et al. (2002) compared BMR corn silage or conventional corn silage cut at 23 or 71 $\mathrm{cm}$ of height at 2 levels of NDF in the diet. Overall, cows fed the BMR corn silage tended $(P<0.09)$ to produce more milk than those fed the conventional corn silage cut at $23 \mathrm{~cm}$, but they produced similar amounts of milk compared with cows fed conventional corn silage that was cut high. Fat-corrected milk was not affected by treatments in that study but milk production was also substantially lower (about $33 \mathrm{~kg} / \mathrm{d}$ ) compared with that in the current study (about $48 \mathrm{~kg} / \mathrm{d}$ ).

Cows fed normal-cut BMR had milk with a greater concentration of lactose but lower MUN compared with other treatments. Similar milk protein percentage but lower MUN might suggest that cows fed BMR corn silage were more efficient in converting feed protein into milk and body tissue. Somatic cell counts were similar among treatments. Feed efficiency for cows fed the BMR silage (1.83) was greater than for those fed high-cut 7511FQ (1.75), but was not different from cows fed the normal cut 7511FQ (1.77). Body weights of all treatments were similar and averaged about $742 \mathrm{~kg}$; BW changes were similar among treatments.

\section{CONCLUSIONS}

Harvesting a normal corn hybrid at a high harvest height increased the concentration of some nutrients in the harvested plant (e.g., CP, starch, and energy) but did not affect NDF digestion. In vitro NDF-D was considerably greater for BMR corn silage compared with the normal- and high-cut conventional silage. High-cut silage had the lowest estimated milk yield per acre of silages when using MILK2006. Cows fed BMR corn silage produced more milk than those fed a normal corn silage hybrid harvested at a normal or high cut when these silages were incorporated into TMR that were made isocaloric and isnitrogenous. Because of this finding, cows fed BMR corn silage were more efficient at converting DM to FCM compared with cows fed highcut corn silage. Dry matter intake was not affected by the type of corn silage in the TMR.

\section{ACKNOWLEDGMENTS}

The authors wish to thank Richard Morris (Dairy Manager), Jon Hummel (Agronomy Manager), and the 
staff of the University Delaware Farm for assistance throughout the study. Partial funding for this study was provided by Mycogen Seeds (Dow AgroSciences), Indianapolis, Indiana.

\section{REFERENCES}

AOAC. 2000. Official Methods of Analysis. 17th edition. Association of Official Analytical Chemists, Gaithersburg, MD.

Dominguez, D. D., V. R. Moreira, and L. D. Satter. 2002. Effect of feeding brown midrib-3 corn silage or conventional corn silage cut at either 23 or $71 \mathrm{~cm}$ on milk yield and composition. J. Dairy Sci. 85(Suppl. 1):384. (Abstr.)

Dominguez, D. D., and L. D. Satter. 2003. Feeding brown midrib-3 corn silage or conventional corn silage cut at either 20 or $66 \mathrm{~cm}$ of height to early lactation cows. J. Dairy Sci. 86(Suppl. 1):231. (Abstr.)

Eastridge, M. L. 1999. Brown midrib corn silage. Pages 179-190 in Proc. Tri-State Dairy Nutrition Conf., Ohio State University, Columbus. Ohio State Univ., Columbus.

Ebling, T. L., and L. Kung, Jr. 2004. A comparison of processed conventional corn silage to unprocessed and processed brown midrib corn silage on intake, digestion, and milk production by dairy cows. J. Dairy Sci. 87:2519-2527.

Goering, H. K., and P. J. Van Soest. 1970. Forage Fiber Analyses (Apparatus, Reagents, Procedures, and Some Applications). Agric. Handbook No. 379. ARS-USDA, Washington, DC.

Holm, J., I. Bjorck, A. Drews and N.-G. Asp. 1986. A rapid method for the analysis of starch. Starch/Die Starke 7:224-226.
Krishnamoorthy, U., T. V. Muscato, C. J. Sniffen, and P. J. Van Soest. 1982. Borate-phosphate procedure as detailed in nitrogen fractions in selected feedstuffs. J. Dairy Sci. 65:217-225.

Lewis, A. L., W. J. Cox, and J. H. Cherney. 2004. Hybrid, maturity, and cutting height interactions on corn forage, yield and quality. Agron. J. 96:267-274.

Morris, T. R. 1999. Experimental design and analysis in animal sciences. CABI Publishing, Wallingford, UK.

Neylon, J. M., and L. Kung, Jr. 2003. Effects of cut height and maturity on the nutritive value of corn silage for lactating cows. J. Dairy Sci. 86:2163-2169.

NRC. 2001. Nutrient Requirements of Dairy Cattle. 7th rev. ed. Natl. Acad. Sci., Washington, DC.

Oba, M., and M. S. Allen. 1999. Effects of brown midrib 3 mutation in corn silage on dry matter intake and productivity of high yielding dairy cows. J. Dairy Sci. 82:135-142.

SAS Institute. 1999. SAS/STAT User's Guide. Version 8. SAS Institute Inc., Cary, NC.

Shaver, R. D., and J. G. Lauer. 2006. Review of Wisconsin corn silage milk per ton models. J. Dairy Sci. 89(Suppl. 1):282. (Abstr.)

Tine, M. A., K. R. McLeod, R. A. Erdman, and R. L. Baldwin VI. 2001. Effects of brown midrib corn silage on the energy balance of dairy cattle. J. Dairy Sci. 84:885-895.

Weiss, W. P., and D. J. Wyatt. 2006. Effect of corn silage hybrid and metabolizable protein supply on nitrogen metabolism of lactating cows. J. Dairy Sci. 89:1644-1653.

Wu, Z., F. Kanitz, and L. D. Satter. 2001. Nutritive value of silage corn harvested at two heights above ground for lactating dairy cows. 2000-2001 Summary. US Dairy Forage Research Center, Madison, WI.

Wu, Z., and G. Roth. 2005. Considerations in managing cutting height of corn silage. Extension publication DAS 03-72. Pennsylvania State University, College Park. 